\title{
Revitalization of Traditional Architecture Towards Sustainable Development of the Skadar Lake Area
}

\author{
Irena Rajković, University of Montenegro \\ Marija Bojović, University of Montenegro
}

\begin{abstract}
Traditional architecture is one of the most important segments in the preservation and development of cultural identity. The Lake Skadar region abounds in examples of vernacular building activity that provide the clearest evidence of the creation of settlements and houses as a result of adaptation to natural environment. The study of vernacular architecture on the shores of Lake Skadar is related to the identification and potential evaluation of its local traditional features, as ecological building forms which express the principle of sustainability. Within the framework of research on vernacular architecture of this area, analysis is undertaken with the aim of defining guidelines for revitalizing traditional settlements in this region. In this respect the emphasis of this work is on recognizing the potential and possible directions in revitalization of cultural heritage of traditional settlements in keeping with the principles of sustainable development.
\end{abstract}

Keywords - Adapting to natural environment, potential, revitalization of cultural heritage, sustainable development, traditional architecture.

This paper's research on the topic of Revitalization of traditional architecture towards sustainable development of the Skadar Lake area aims to draw attention to the vernacular qualities of authentic rural architecture in consideration of revitalization of traditional settlements in accordance with the principles of sustainability. Lessons of traditional (vernacular) architecture represent the basis for the principles of environmentally responsible construction engineering and environmentally sustainable development in general. Traditional architecture, as a regional language of architecture, is a powerful inspiration and catalyst for future realizations based on the idea of preservation of local and regional recognisability of architecture.

The area of Montenegrin karst, especially the Skadar Lake basin as part of this region, abounds in examples of traditional construction engineering that testify best in the emerging settlements and houses, as a result of adapting to natural environment. The principles of construction engineering express bioclimatic aspects that highlight interaction between the conditions of natural environment and architectural responses to them.

Abandoning of the traditional way of doing business, life and housing culture, that happened in the second half of the twentieth century, caused degradation of authentic traditional residential and commercial architecture.

Revitalization of traditional architecture refers to possibilities of improving the functional and energy characteristics of folk architecture in the Skadar Lake area, by considering bioclimatic interventions. This research includes also a review of the concept, as well as other aspects of revitalization of rural settlements.

\section{CHARACTERISTICS AND TYPOLOGY OF SETTLEMENTS IN THE SKADAR LAKE AREA}

Dinaric karst area with its arable land, as the basic and most important condition for establishment of settlements, is a region where rural settlements are mainly located at the very borders of arable land (fields, trough), between fertile land on the one side and rocky, arid soil on the other side.

The main motive for such a positioning of settlements was the protection of valuable arable land, which was the basic condition for people to live there, as well as protection from possible flooding of settlements in periods of prolonged winter rains. Villages in the area of the Montenegrin Karst are largely located on the sunny sides, usually on the eastern and southeastern slopes.

The following settlements are typical for the Skadar Lake area: dense-type and scattered-type settlements, as well as transitional-sparse-type settlements.

Dense type settlements are widespread on Skadar Lake. Houses are placed on a hill or at the foot of a hill. Houses are detached, allowing for walkways. In some cases, houses lean on each other. This type of village has been greatly influenced by the morphology of the terrain, as well as climate conditions.

Scattered type settlements are villages consisting of houses distanced 400 to 800 metres. This type of settlement is influenced by the morphology of the terrain; because in this type of village land is not grouped in one area (Jankovići, Đinovići, Bobija etc.).

Transtional sparse type settlements are characterized by small to large houses, distanced 300 to 400 metres and arranged on a large parcel of land [6].

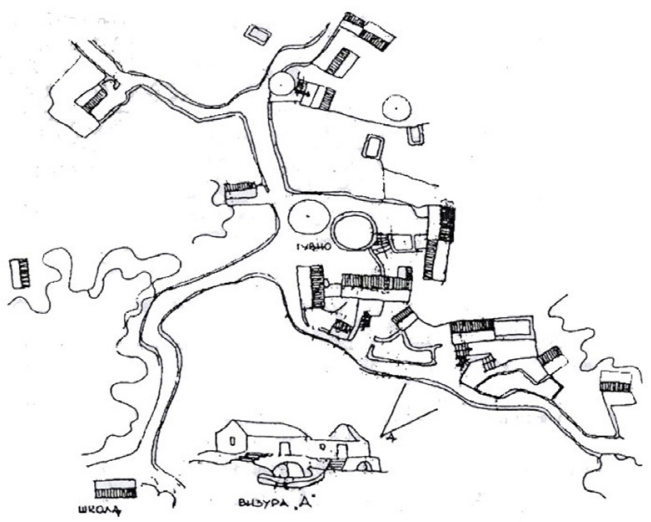

Fig. 1. Typical characteristics of settlement of the Montenegrin karst: brotherhood groupation on the edge of the bay (hamlet Batrićevići, village Očinići) [6]. 

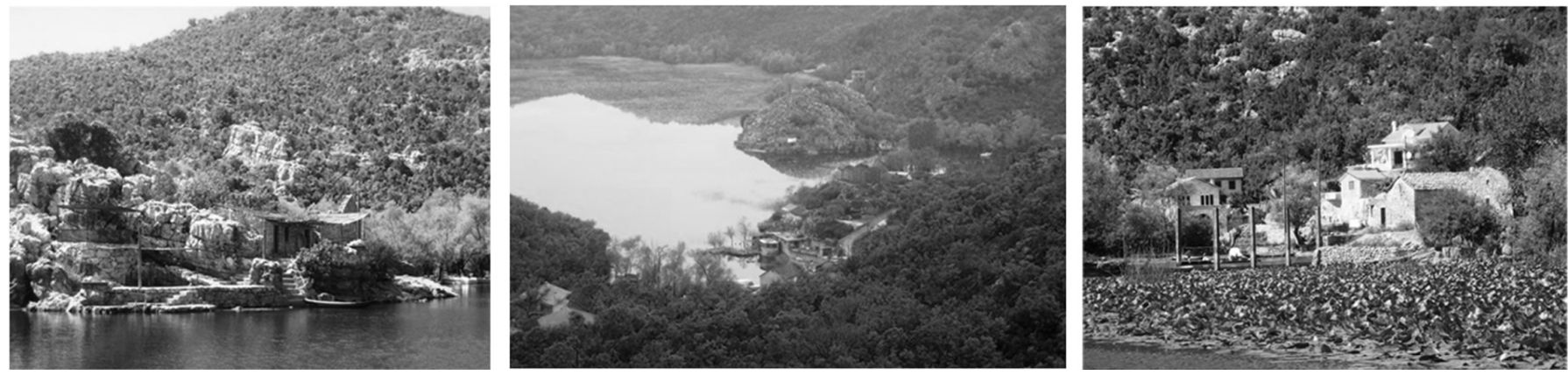

Fig. 2. Karuč, Skadar Lake, Montenegro [Pictures: Irena Rajković].

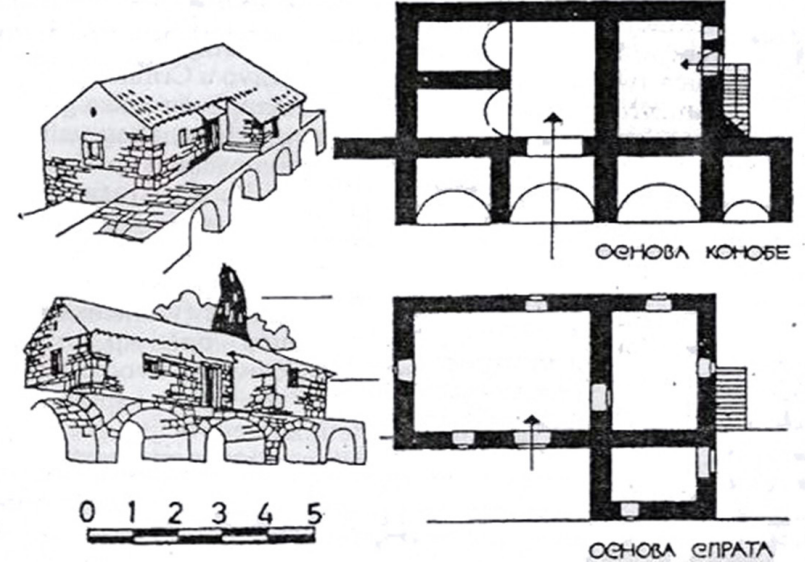

Fig. 3. House parallel to contours as a subtype: open external staircase and a terrace ("teraca") with "pidžunom" located on the front side of the house [1].

The main characteristics of formation of spatial matrix of settlements are mostly affected by relatively small available space, suitable for forming the housing (Fig.1).

As the specificity of this settlement unit in the surroundings of the National Park Skadar Lake, attention is drawn to the old fishing village Karuč (Fig. 2.), as a seasonal village for storage and disposal of fishing equipment and processing of the catch. It has taken hold as a permanent settlement in the middle of the last century.

However, the village as such is gone, its former residents have moved to the cities, while only a small number of people still live there, and most of the village houses have collapsed. Thus, the tradition suddenly passed into history and archaeology.

\section{CHARACTERISTICS OF HOUSES IN THE AREA}

\section{A. Typology}

Village settlements of the Old Montenegro were mainly developed along fertile land, at the foot of the stony and mostly sunny sides and in areas sheltered from the wind. Architectural image of settlements of the Old Montenegro can be defined as uniform and simple. Due to significant similarities, houses in the coastal region and houses in the karst area could be grouped into a single type, but due to certain differences highlighting the uniqueness, as well as variations regarding the subareas,

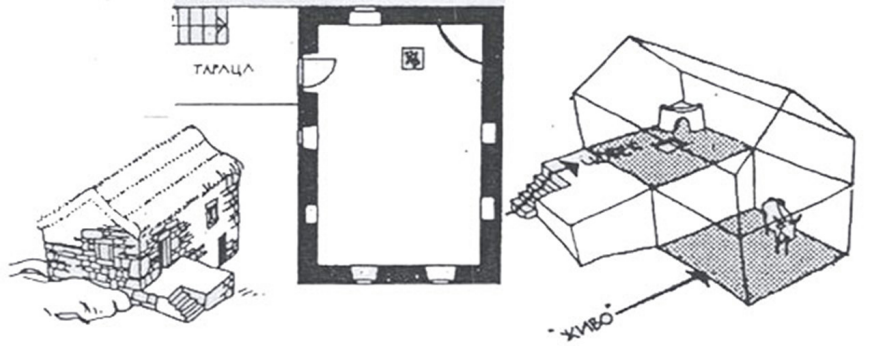

Fig. 4. Houses vertically on contours as a subtype: low terrace with a staircase located on the side (the longer side of the house) [1].

houses in the area of Montenegrin Karst are analysed separately by typology.

The three basic types of settlements that stand out in terms of number of floors are as follows: prizemljuša (or ground-level house), storey house (or house on den) and a house with two floors (or two-story house) [7].

In addition to these basic types of houses, there are also subtypes, incurred as a result of differences in position in relation to the terrain, and these are as follows: houses parallel to contours and houses vertical on contours (Fig. 3), (Fig. 4).

The main features of the house parallel to contours are that the tavern is under the whole house, it has an open external staircase and a terrace with "pidžun" (stone masonry benches along the front wall of the house, covered with vines), then the attic ("petar"), which was used for drying meat or fish, as well as a storage for grain placed under a gabled roof covered with ćeramida ("roof tile"). A very important architectural element in this type of houses is a massive arch called "volat", particularly for large terraces which lie on multiple vaults.

The most important feature of the house vertical on contours is that under the front half of the house there is a tavern, and the other half of the house is lying on a rock. It has led to the formation of a more pronounced "additional" cubic element and since there are no vaults, the terrace with staircase has a much 

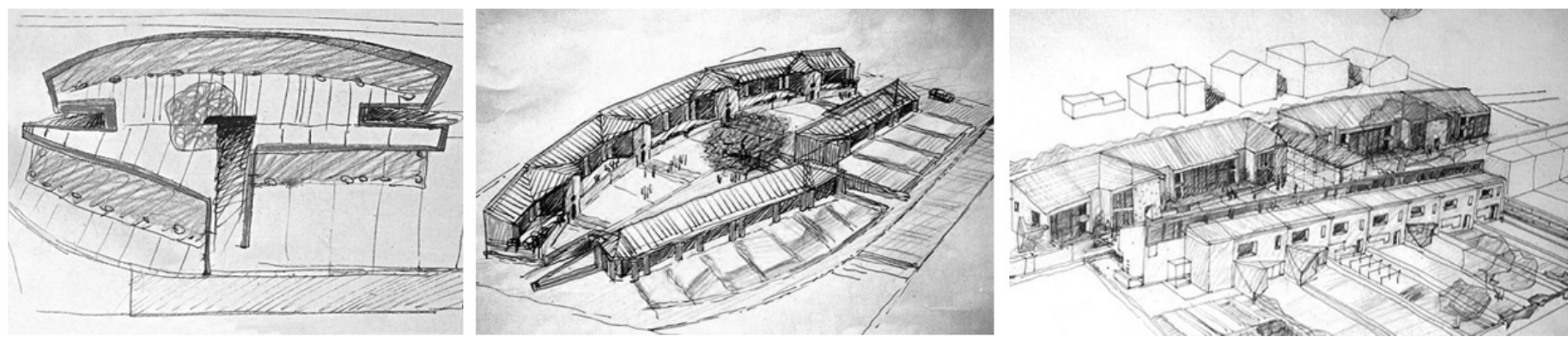

Fig. 5. Drawings of the bioclimatic settlement Santa Agata di Lana, Italy [10].
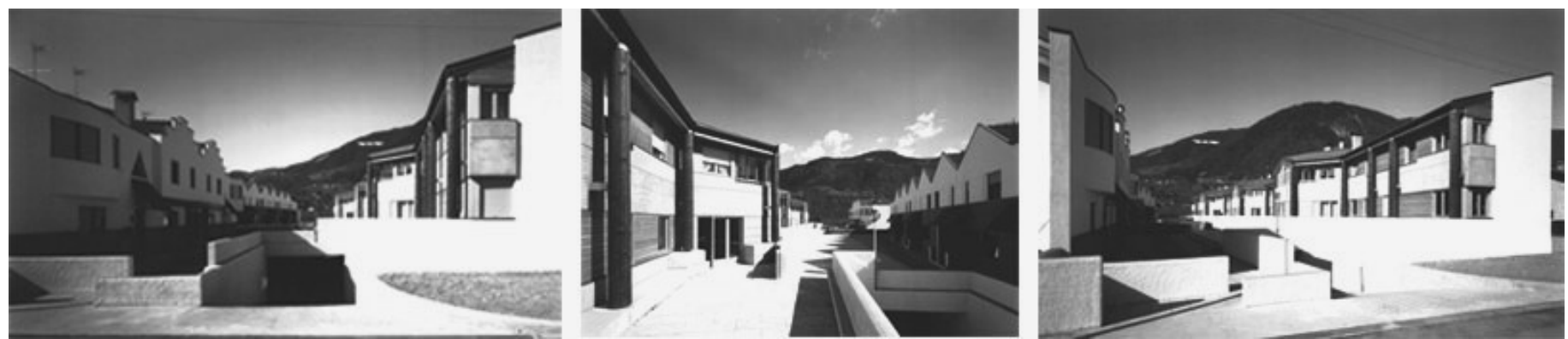

Fig. 6. Completed facilities of the bioclimatic settlement Santa Agata di Lana, Italy [10].

smaller share in the architecture of the whole, compared to the situation in the house parallel to contours [1].

\section{BIOCLIMATIC ASPECTS OF CONTEMPORARY INTERPRETATIONS OF THE EXAMPLES OF TRADITIONAL ARCHITECTURE}

In the world there are settlements that are successful examples in the context of traditional structures, which can be inspiring for further development and for the establishment of new settlements, modeled on motifs from folk architecture.

This process of reviving traditional architecture exists all over the world, and such examples exist in almost all parts of the world. Revitalization of atraditional settlement is carried out through the rehabilitation of buildings and their vernacular architecture primarily energy rehabilitation, through which objects come to life and to an appropriate purpose.

Such a project of bioclimatic village is Santa Agata di Lana, near Merano, Italy (Fig. 5), (Fig.6). The main objective in designing this settlement was to maximize the responses to environmental conditions, at the same time meeting the requirements in the historical and geographical context and energy saving.

This project is an example of alignment with the ambient quality while preserving the history and geography of the place. Thoughtful approach and adequate analysis of the structure, was the response to the extreme conditions of a very cold winter, and on the other hand an extremely hot summer.

One of the recent examples of contemporary interpretation of vernacular architecture and successful solution of bioclimatic design is also a private villa complex in Greece, the place Spetses. It was designed in the way to illuminate the traditional coastal architecture of the Greek islands by contemporary expression, respecting all natural conditions of the location where the buildings were built. Special attention was paid to the passive design, and active systems in the use of solar power, a particularly interesting application of vertical shades that is the protection from solar radiation, create interesting interior environments and areas at the same time (Fig. 7).

The author of the project did not aim at merely copying traditional architectural elements, but did interpretation, which reflected the spirit of the time, when the buildings had been created. At the same time, he did not neglect the tradition and identity of the area, but gave them a new expression and improved in line with technological possibilities of the moment.

Another example of design and construction based on the principles of traditional architecture, but through a new contemporary expression, is a private Complex object in Bijač, Bosnia and Herzegovina. This complex fully relies on the tradition of the place, its identity and originality of the material of which it is built. The architectural language is elementary, minimalist kind of fitting the place where the objects are constructed. Through the designing process-the positioning of the buildings was taken into account, so that buildings do not impair the view of each other, as well as the maximum adjustment to the conditions of the terrain. Houses are made by bioclimatic principles and equipped according to the latest environmental standards and requirements (Fig. 8).

\section{POSSIBILITIES OF REVITALIZATION OF \\ TRADITIONAL RURAL SETTLEMENTS THROUGH SUSTAINABLE DEVELOPMENT}

Sustainable development of the Skadar Lake includes conservation of nature of the lake, construction engineering, architectural and cultural heritage, and consequently the greatest 

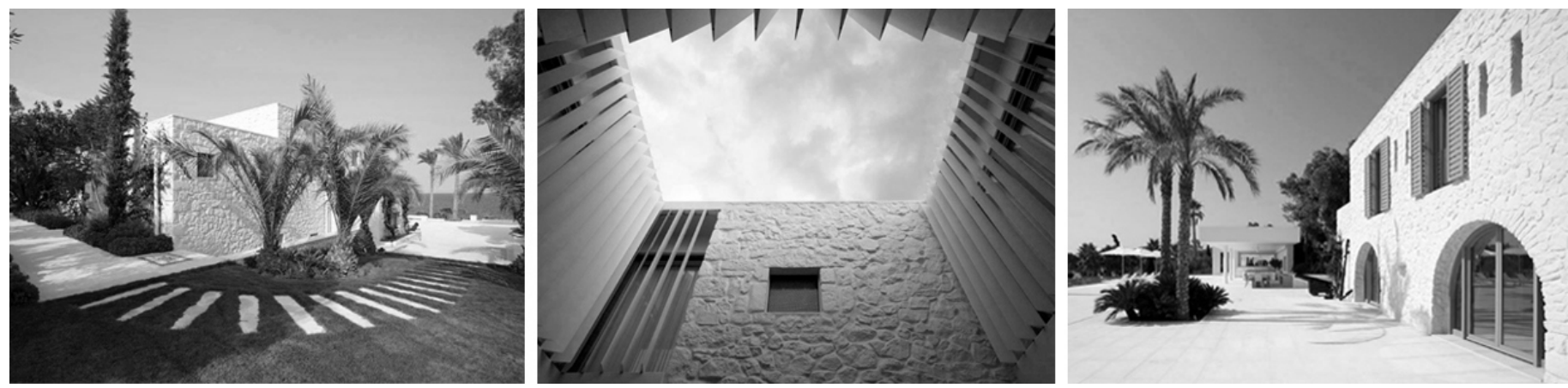

Fig. 7. Contemporary expression of traditional architecture on the island of Spetses, Greece [11].
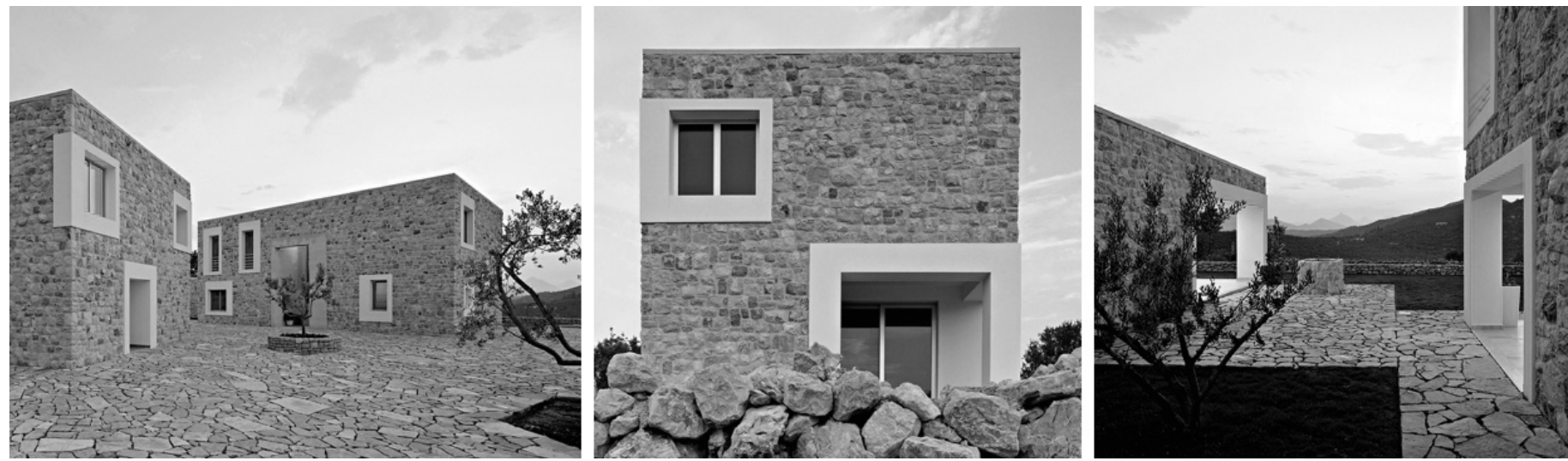

Fig. 8. The family estate with a complex of houses, Bijač, $\mathrm{BiH}[12]$.

caution is needed in planning and construction. Sustainability of this area includes preservation of specific local environment and life within the settlements and structures. Value layers that are deposited in these rural communities (architectural, urban, ethnological, historical and cultural) express the need for these communities to receive appropriate professional care. Therefore, revitalization and purposeful use of architectural heritage in relation to the construction of new housing and tourist facilities in the area need to be encouraged.

A. Architectural and Technological Aspects: Bioclimatic Principles and Possibilities for Use of Renewable Energy Sources

Challenges of protecting traditional architecture, when the old spatial cores are in question, are very specific as it is about preserving the tradition of people in the particular area. In this respect, it is important to pay particular attention to preservation of traditional architectural forms, through both revitalization of the existing, as well as construction of new structures in these areas. Architectural aspects of protection are reflected in construction with materials that are natural and autochthonous as well as in the skilful use and application of modern materials in the new structures. Such structures must indicate the time of their construction, but with respect for the space-time components of the old part of the settlement. This new architecture must neither be imposed nor take a major impression. It is about respect for the traditional architectural lines, conscious and very organized support to such houses and villages being looked after and maintained, and developed, but in their own spirit. In the protected cores it is necessary to avoid content that could contribute to their degradation and develop those who compliment a contemporary lifestyle. It is necessary to have an active and thoughtful attitude towards the settlements of this area, with their potential and resources for sustainable development of the area.

Current methods of renovation and reconstruction of the existing, as well as construction of the new structures, should be based on preservation of traditional physical structures of rural settlements through the promotion of bioclimatic characteristics and the use of new technological opportunities.

\section{ANALYSIS OF CHARACTERISTICS OF FOLK ARCHITECTURE IN THE EXAMPLE OF THE SETTLEMENT KARUC̆}

In the area of Skadar Lake in the vicinity of certain cultural properties, there are also examples of folk architecture, which are recommended for preservation due to their environmental values. Such an example is the small fishing village Karuč, located on the outer north-eastern region of the Lake's bay of the same name (Fig. 9). Erstwhile, Karuč had a character of a temporary settlement and was not permanently settled.

It is a dense type settlement. Houses are generally freestanding and there is walkway possible between them and passage to each 


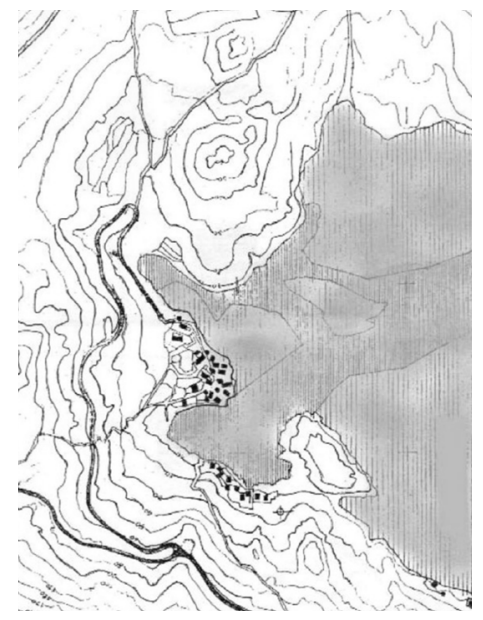

Fig. 9. Village Karuč, Skadar Lake, groupation of houses [7].

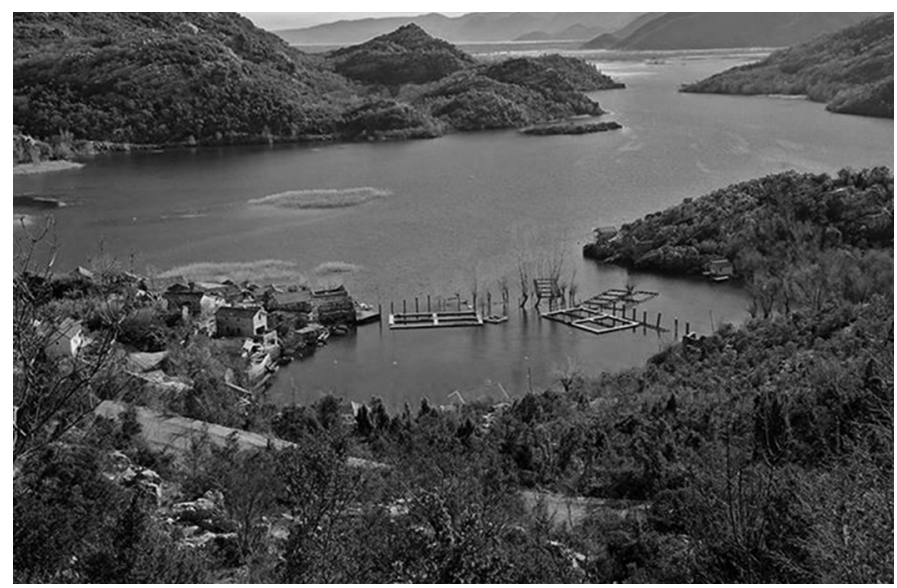

Fig. 11. Karuč, view of Karuč bay and settlement [Picture: Irena Rajković].

of them, while certain houses lean on each other (Fig. 6). Most of them are dilapidated, some of them are left only with their housing, while only a few houses have been renovated in which people live mostly during the summer months, from spring to late fall, dealing with recreational fishing and sporadically with hospitality.

The fishing village is dominated by the winter home of St. Petar of Cetinje (Petar I Petrovic Njegos), which is currently in a very poor and neglected state. Karuč with its authentic architecture and specific position, the distinctive Tower of St. Petar, Volačko and Karučko oko (springs) and with favourable communication is a settlement which by all the elements of environmental values of the particular region deserves careful approach in planning and implementing urban revitalization.

\section{A. Natural Factors in Formation of Settlements - Urban Aspects}

Karuč is located on the north shore of the Skadar Lake, on a slope south oriented and belongs to the settlements of densetype housing. Altitude goes from $6 \mathrm{~m}$ above sea level, which is the height on the shore of the lake, and up to $25 \mathrm{~m}$ above sea level at which the Tower of St. Petar is located. Since the terrain

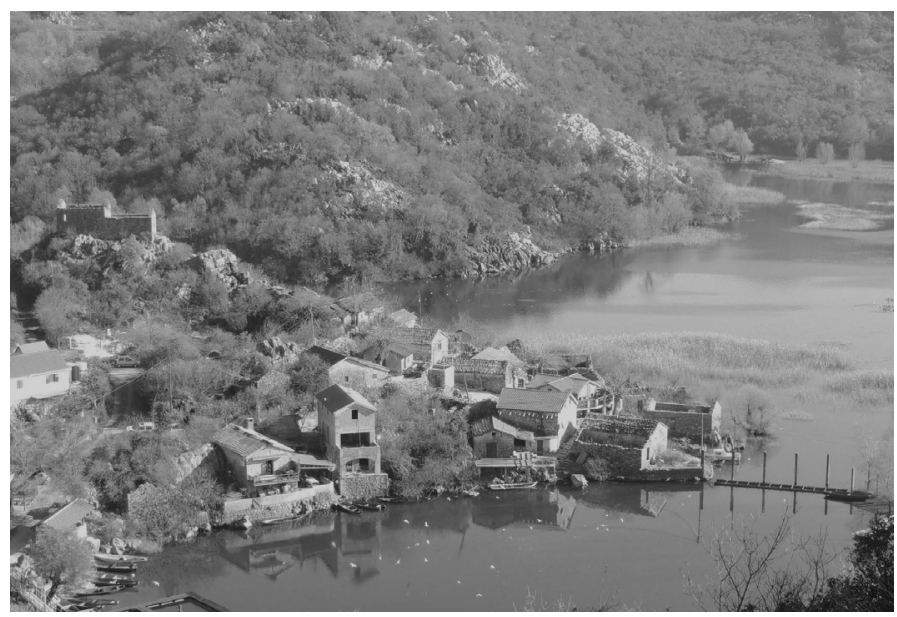

Fig. 10. Village Karuč, Skadar Lake, the current situation of the groupation of houses [Picture: Irena Rajković].

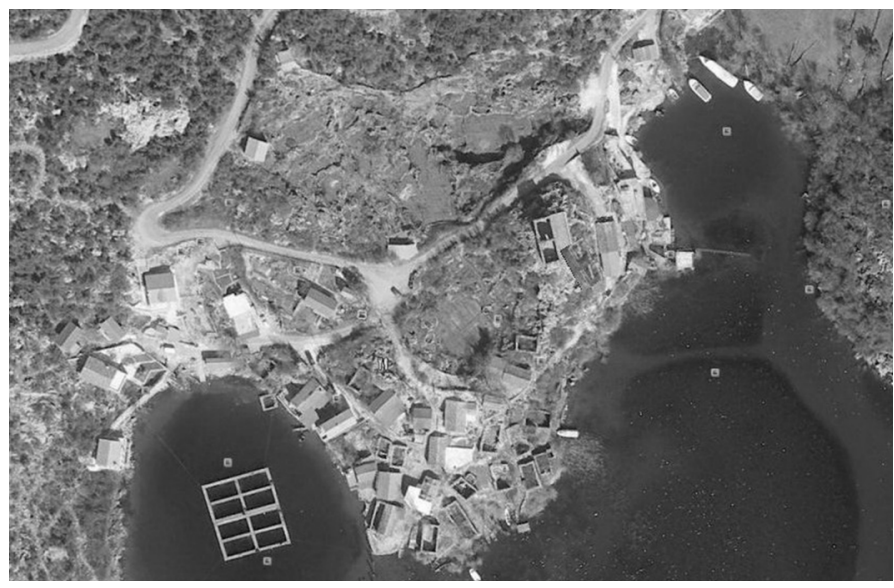

Fig. 12. Settlement Karuč, satellite imagery [Picture: Google Earth].

is in slope, the houses are positioned vertically on contours, at a short distance from each other, while certain houses lean on each other.

\section{B. Analysis of Topographic Conditions and Morphology of} the Settlement

The location on which the settlement Karuč was created stands out with its specificities. It is characterized by an exceptional natural environment and unique landscape (Fig. 11). In a broader sense it is a mountainous area that in some places even descends steeply into the lake. Microrelief of the specific location of the settlement was launched. Such a terrain in slope and topographic features of the place influenced the emergence of groupation of dense type houses, positioned vertically on contours. The structures are ground level, so that in addition to the favourable mutual positioning they do not threaten the view and access to the lake not even with their height. The Tower of St. Petar was constructed on the highest altitude, while the houses were situated at its base, close to the shore.

The position of houses along the lake enabled unrestricted and easy access to water or dealing with fishing and all that is related to the basic economic activity of the population of this place. 

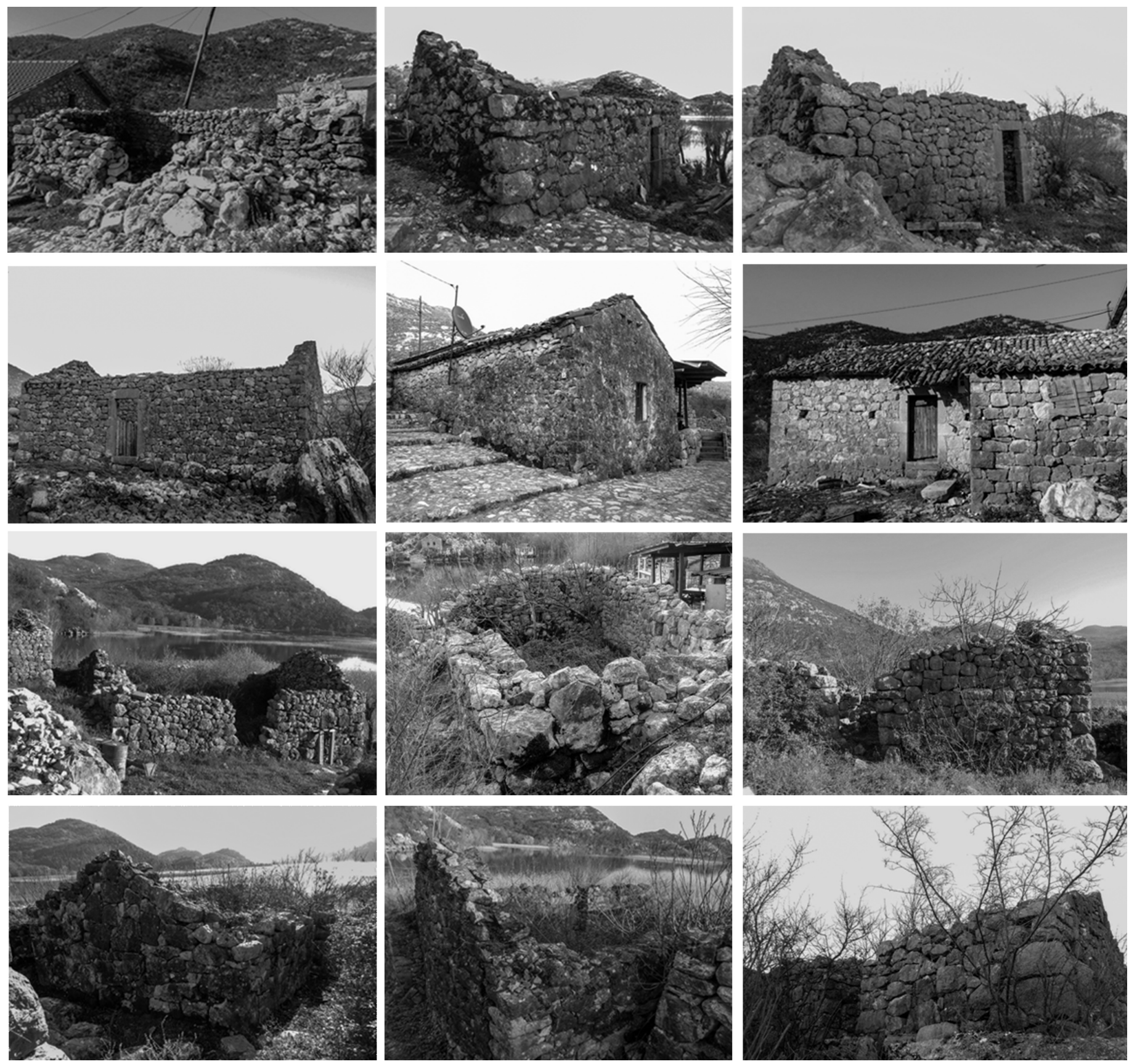

Fig. 13. The view of authentic houses in the settlement Karuč, current situation [Pictures: Irena Rajković].

The specificity of the terrain and environment, on which the traditional architecture of this place was formed, has conditioned their perfect fit into the terrain and the mutual relations of houses, which enable the view of the lake. The dominant image of the landscape and the house that follows the natural terrain configuration and its unpretentious folk architecture create the harmony of nature and the constructed.

The folk builder respected the characteristics of the location, so the houses were built to emphasize the features of the environment and the specificities of the location, and therefore the meaning of the term genius loci, as a spirit-patron of the place, gets its full meaning in this place.

By analysing the vernacular architecture created at the location, it is clear that the folk builder based on his experience and knowledge of natural features of the place where he lived and worked constructed in harmony with nature, respecting its conditions and laws. He built structures without compromising the environment, but also used the natural advantages in order to enable the creation of maximum comfort to stay in the constructed houses. Although seemingly very simple and reduced architecture of the settlement, it is a very good example of bioclimatic response to natural conditions of the location. 


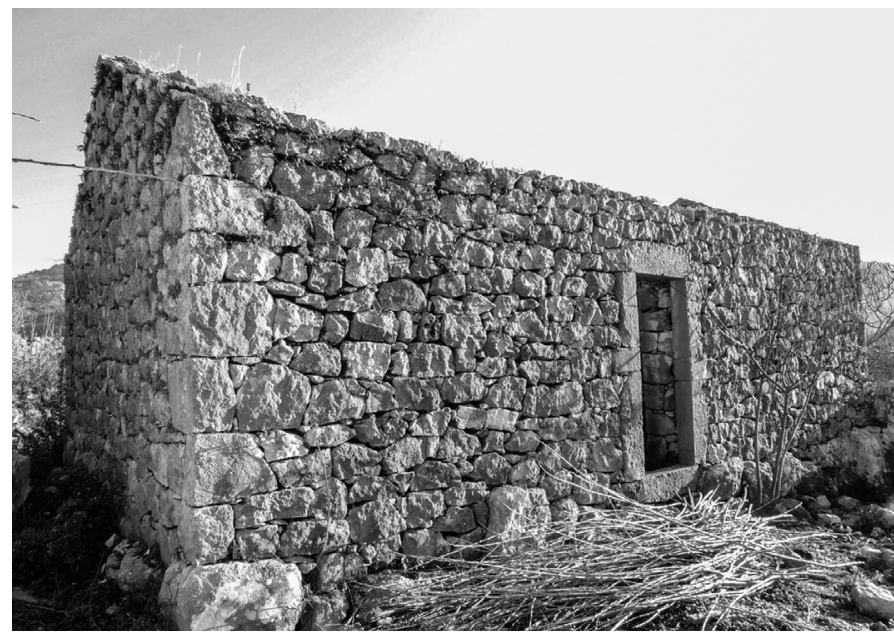

Fig. 14. Housing of autochthonous house in Karuč [Picture: Irena Rajković].

\section{Analysis of a Typical House Within the Settlement -} Architectural Aspect

\section{Position and Orientation of the house}

The Karuč settlement with its typical architecture represents an extraordinary example of vernacular architecture, which is a significant combination of tradition and culture. It is almost impossible to view individually the architecture of a house in Karuč, as the entire settlement is a unique agglomeration, which has environmental and cultural dimensions. A very important aspect of the architecture of the settlement is that it represents a unique response to specificities of the location where it has been created. Houses built in this area carry the spirit of place (genius loci), lifestyle and spirit of people who lived and worked there. The spirit of the house exceeds its practical function that was supposed to satisfy local needs of the population to have a pleasant stay and allow for unhindered fishing, as the basic economic activity of the place.

Autochthonous houses form a groupation, which functions as a unique traditional settlement which arose primarily as a temporary settlement with a character of a katun (hut). The houses in this location were built with maximum respect for the characteristics of the terrain, which is in the slope and they fit in with the terrain configuration (Fig. 13).

A typical house of the settlement Karuč is positioned vertically on contours, with the longer axis generally in the northeastsouthwest direction. The orientation of the house is adapted to the configuration of the terrain and this type of ground-level house is formed in a manner to maximumally use the natural slope of the terrain. The entrance doors of most of the houses were set up on the west side, and very small openings were located on the west side of the house facing the lake.

The windows are smaller, rectangular, mostly made in the ratio of $1: 2$, and are framed by stone beams. Beside the window, there are openings formed by dropping a stone in masonry, which are mainly under the roof and are intended for ventilation.

The function of a house was conditioned by the lifestyle and needs of a man who lived in this area. The space of the house in which the required functions were performed was small in
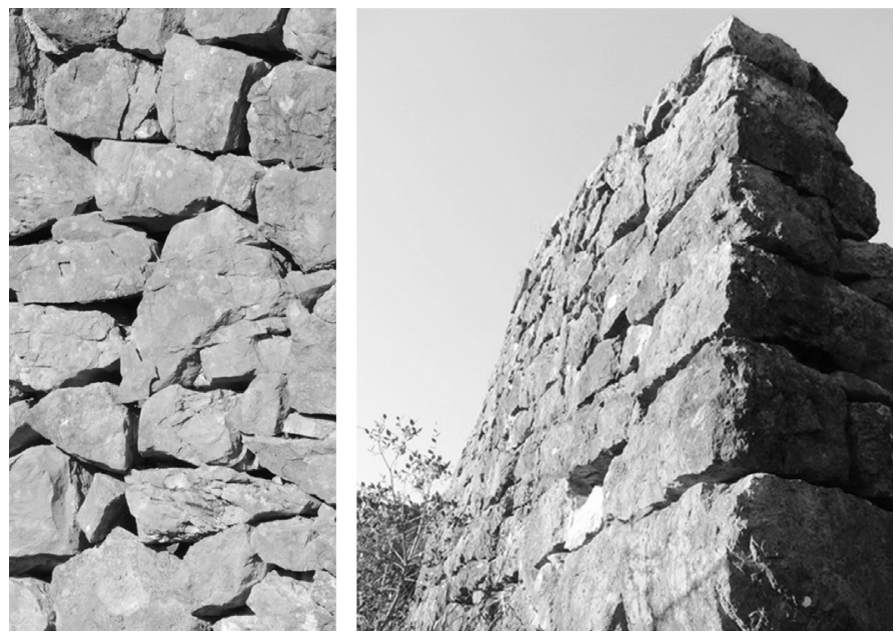

Fig. 15. Stone arrangement-constructing a wall “in dry”[Picture: Irena Rajković].

size, everything was very modest, but enough to meet the basic conditions of life and stay in these houses.

\section{Formation and Local Architectural Expression}

The main characteristic feature of a typical house in Karuč is adaptation to the environment. It belongs to the type "prizemljuša", one of the oldest types of houses in this area, which has one or two rarely smaller windows. The simple architecture of harmonious proportions and balance of visual elements are the main characteristics of houses in Karuč, due to decoding the basic conditionality of context.

\section{Materialization and Construction}

As regards materialization of houses in Karuč, the basic material is stone, in accordance with abundance and availability of this natural material in this area. The stone was used to build the massive walls of houses. The stone was used for building retaining walls, fences and secondary facilities using the dry technology, untreated or very little treated ashlar masonry with a thickness of about $60 \mathrm{~cm}$ (Fig. 15). The sets of which the walls were made are irregular, except for some more properly processed angles. In addition to stone the use of wood is present as another natural material, which is used for making the structural element of the roof and resolving aperture and for making interior elements in houses. The roof covering is ćeramida (channel).

\section{THE STUDY OF (POSSIBILITIES) INTERVENTIONS IN THE EXAMPLE OF THE SETTLEMENT KARUC̆}

The case study of the improvement of bioclimatic characteristics of the Karuč settlement in the Skadar Lake area primarily includes guidelines for the purpose of revival of the settlement through activation of economic activities for population to deal with, and tourism that would attract many visitors.

Accordingly, revitalization of the settlement requires a multidisciplinary approach. Adequate approach to revitalization 

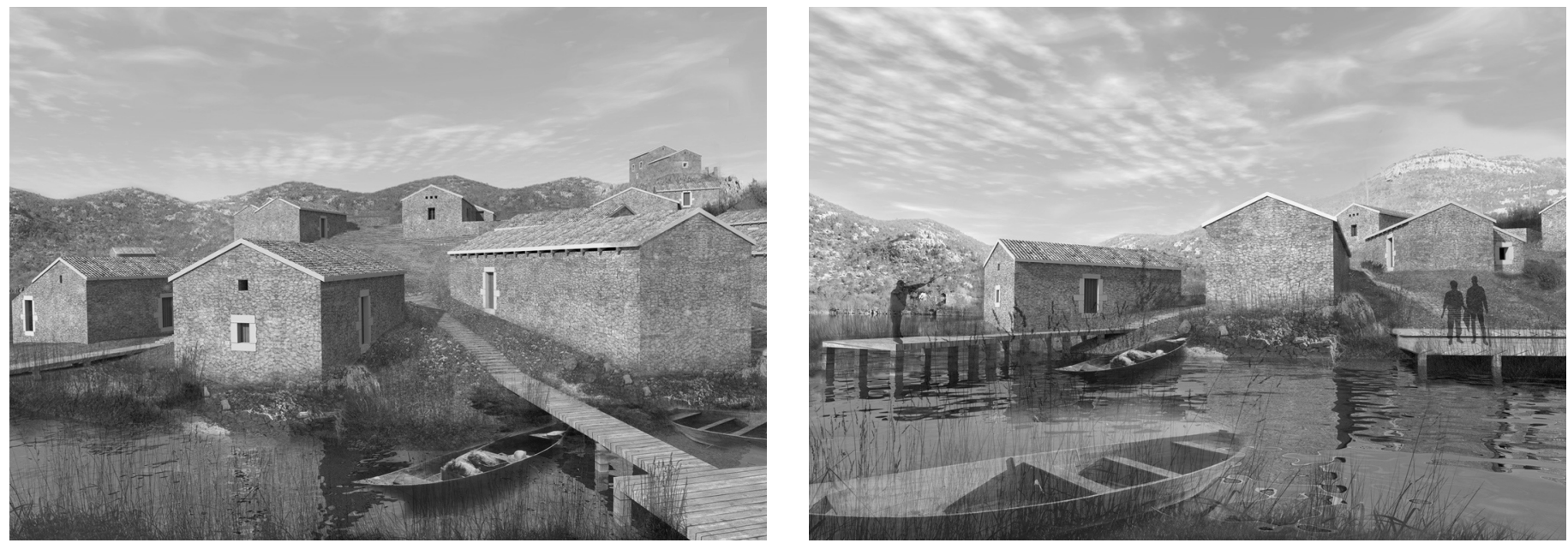

Fig. 16. Visualization of possible revitalization of the groupation of authentic houses in Karuč [Pictures: Irena Rajković].

of the traditional settlement primarily imposes the need to preserve its authentic urban - architectural, artistic - aesthetic and environmental values. Therefore, during rehabilitation and reconstruction, especially in the case of possible construction of new structures in this area, the basic guideline should be the reinterpretation of local typological characteristics in accordance with modern architectural, functional, construction, technology, energy and landscape solutions, avoiding formalistic and widely accepted styles of construction and imitation of traditional houses. For the purpose of adequate interventions for revitalization of the settlement a case study is being developed using the example of Karuč and its authentic architecture. Based on the research and previous analysis a model is given for a possible revitalization of the village and its architecture.

It is necessary to note that based on the research of vernacular architecture, which was created on this locality, it is primarily proposed to renew authentic village houses of the settlement Karuč. Although most of the structures are in ruins, it is possible on the basis of existing housing, old photos, better preserved or already reconstructed individual structures to revive the former image of the groupation of houses in Karuč. Revitalization involves restoring the architectural image of the village, but also the promotion of bioclimatic characteristics of revitalized structures through their energy rehabilitation. During the revitalization of the entire settlement it is necessary to take into account preservation of harmony between nature and the constructed, which represents the primary characteristic in assessing the quality of the traditional architecture of this place. It involves preserving the traditional physical structure and thereby keeping the position and dimensions of the existing structures.

A large number of houses in Karuč are in ruins, in some cases only remains of the facade walls are present, which on one hand is a problem in terms of more extensive work for adequate reconstruction, but on the other hand gives the possibility of applying appropriate measures aimed at quality and professional renewal of authentic houses.
Construction of new structures is possible assuming that by their architectural expression they fit into the existing environment. This adjustment of new structures should not be seen as a mere imitation of the existing surrounding structures, but as a certain association with the old architecture of the area transformed into a new form, new volumes and their spatial relations. New residential structures follow the inherited morphological structure with their size. Innovation must be in the spirit of the time in which it is done and then it is a revival of the tradition through new contemporary models, with respect for traditional principles. In order to present the possible revitalization of authentic architecture we made a threedimensional simulation of revitalized traditional houses, which represent the specific and unique groupation of the settlement Karuč. The overview provides a possible image through the scenario that involves renewal of houses, which have previously existed in this area, and revival of the former architectural image of the area (Fig. 16).

Based on this visualization, we present a proposal of the image of revitalized settlement Karuč. Ambience of the complex draws on the tradition of the village, memory of the place and authenticity of the material of which it was built. The architectural language is simple and reduced, exactly as befits the landscape, to properly fit and create unity with the surrounding. It is designed so that everything can be realized by local builders and by using locally available materials.

\section{CONCLUSION}

Traditional architecture resulting in collusion with nature creates a balanced and environmental rhythm of life and stresses the attitude towards climatic and topographical realities and the spirit of place (genius loci). It represents a response to natural conditions of the place where architecture emerges. However, it is necessary to have a critical attitude towards tradition and what makes the tradition. Such a sincere and thoughtful approach should be the aim of contemporary architecture as well, where 
the use of traditional architectural elements should be the result of a thoughtful approach, analysis, and even critical attitude towards tradition and ancestral architecture.

The case study conducted in the example of the village Karuč in the area of Skadar Lake contributes to shedding light on the possibilities of architectural and energy rehabilitation of traditional architecture with the aim of its revitalization.

The research conducted in this paper was aimed at identifying potential and possible directions and models of revitalization of similar rural traditional localities in accordance with the principles of sustainable development.

\section{REFERENCES}

1. Kojić, B. Seoska arhitektura $i$ rurizam-teorija $i$ elementi. Beograd: Građevinska knjiga, 1973. 260 str.

2. Petrović, B., Rašković, I. Tradicija-tranzicija : upotreba nasljeđa arhitekturi. Belgrade: Orion Art, 2011. 175 str. ISBN : 978-86-83305-43-8

3. Rudofski, B. Arhitektura bez arhitekata. Beograd: Građevinska knjiga, 1976. 8 str.

4. Norberg-Šsulc, K. Egzistencija, prostor $i$ arhitektura. Beograd: Gradjevinska knjiga, 2002

5. Miller, D. Towards a new regionalism-Environmental Architecture in the Pacific Northwest. Seatle: University of Washington Press, 2005. 174 p.

6. Vuksanović, D. Tradicionalna arhitektura Crne Gore i bioklimatizam. Belgrade: Zadužbina Andrejević, 1998.

7. Popović, S. G. Arhitektonsko nasljeđe basena Skadarskog jezera. Podgorica: Ljeto i Dodošima, 2007. 88 str.

8. Szokolay, S. V. Introduction to Architectural Science : The Basis of Sustainable Design. Oxford: Architectural press, 2004. 356 p.

9. Olgyay, V. Design with climate : Bioclimatic approach to architectural regionalism. Princeton, New Jersey: Princeton University press, 1963 $236 \mathrm{p}$.

10. Los, S., Pulitzer, N. F. Una Contrada Bioclimatica a Lana Dimerano. Europolis, Vol. 11, Issue 85, 1995, p. 4-27. Available also at: http:// synergiaprogetti.com/it/ecovillaggi-e-micro-citt\%C3\%A0/item/211contrada-bioclimatica-a-lana-di-merano.html

11. Diverty Architects [online]. Spetses Summerhouse [cited: 10.10.2015]. http://www.divercityarchitects.com/index.php/projects/housing/spetses house

12. Granice [online]. Oris [cited 10.10.2015]. http://www.oris.hr/hr/casopis/ clanak/[18]granice,322.html

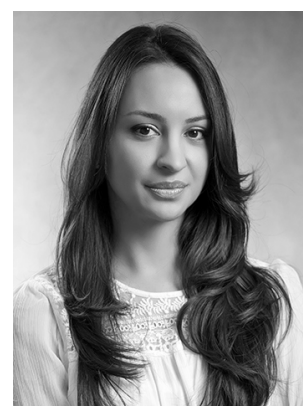

MSc Irena Rajković (1984) obtained her degree in architecture from the Faculty of Architecture in Podgorica, Montenegro in 2008. She has been a Visiting Scholar at the School of Architecture Design and Built Environment, Nottingham Trent University in 2009. In 2014 she received her Master degree from the Department for Bioclimatic and Energy-Efficient Architecture, the Faculty of Architecture in Podgorica, where she has been a teaching assistant since 2009. She is currently pursuing her $\mathrm{PhD}$ studies in architecture with the Faculty of Architecture, University of Sarajevo.

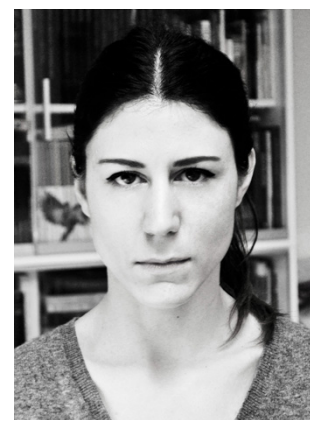

MSc Marija Bojović (1983) obtained her degree in architecture in 2007 from the Faculty of Architecture, University of Belgrade, and Master degree in Advanced Architectural Design in 2012 from prestigious Barcelona Institute of Architecture. Her master thesis addressed issues of open systems and thermodynamic and sustainable architectural design. She is a teaching associate with the Faculty of Architecture, University of Montenegro. Her main research interest is the city. She is currently pursuing her doctoral studies and advocating the necessity of combining theory and practice.

\section{CONTACT DATA}

\section{Irena Rajković}

University of Montenegro, Faculty of Architecture

Address: Džordža Vašingtona Blvd. bb, Podgorica, 81000, Montenegro

E-mail: irena.rajkovic@ac.me irena_arhi@yahoo.com

\section{Marija Bojovic}

University of Montenegro, Faculty of Architecture

Address: Džordža Vašingtona Blvd. bb, Podgorica, 81000, Montenegro

E-mail: marijab@ac.me trashandvaudeville@gmail.com 